University of Nebraska - Lincoln

DigitalCommons@University of Nebraska - Lincoln

USDA Wildlife Services - Staff Publications

U.S. Department of Agriculture: Animal and Plant Health Inspection Service

2010

Epizootic Hemorrhagic Disease Outbreak In A Captive Facility Housing White-Tailed Deer (Odocoileus Virginianus), Bison (Bison Bison), Elk (Cervus Elaphus), Cattle (Bos Taurus), And Goats (Capra Hircus) In Colorado, Usa

\author{
Pauline Nol \\ USDA-APHIS, pauline.nol@aphis.usda.gov \\ Cecilia Kato \\ National Wildlife Research Center, Fort Collins \\ Will K. Reeves \\ USDA/ARS \\ Jack Rhyan \\ US Department of Agriculture, jack.c.rhyan@aphis.usda.gov \\ Terry R. Spraker \\ Colorado State University - Fort Collins, terry.spraker@colostate.edu \\ See nextpage for additional authors Foltow this and additional works at:https://igitalcommons.unl.edu/icwdm_usdanwrc
}

Nol, Pauline; Kato, Cecilia; Reeves, Will K.; Rhyan, Jack; Spraker, Terry R.; Gidlewski, Thomas; VerCauteren, Kurt C.; and Salman, Mo, "Epizootic Hemorrhagic Disease Outbreak In A Captive Facility Housing WhiteTailed Deer (Odocoileus Virginianus), Bison (Bison Bison), Elk (Cervus Elaphus), Cattle (Bos Taurus), And Goats (Capra Hircus) In Colorado, Usa" (2010). USDA Wildlife Services - Staff Publications. 1343.

https://digitalcommons.unl.edu/icwdm_usdanwrc/1343

This Article is brought to you for free and open access by the U.S. Department of Agriculture: Animal and Plant Health Inspection Service at DigitalCommons@University of Nebraska - Lincoln. It has been accepted for inclusion in USDA Wildlife Services - Staff Publications by an authorized administrator of DigitalCommons@University of Nebraska - Lincoln. 


\section{Authors}

Pauline Nol, Cecilia Kato, Will K. Reeves, Jack Rhyan, Terry R. Spraker, Thomas Gidlewski, Kurt C. VerCauteren, and Mo Salman 


\title{
EPIZOOTIC HEMORRHAGIC DISEASE OUTBREAK IN A CAPTIVE FACILITY HOUSING WHITE-TAILED DEER (ODOCOILEUS VIRGINIANUS), BISON (BISON BISON), ELK (CERVUS ELAPHUS), CATTLE (BOS TAURUS), AND GOATS (CAPRA HIRCUS) IN COLORADO, USA
}

\author{
Pauline Nol, D.V.M., M.S., Ph.D., Cecilia Kato, Ph.D., Will K. Reeves, Ph.D., Jack Rhyan, D.V.M., \\ M.S., Terry Spraker, D.V.M., Ph.D., Dipl. A.C.V.P., Thomas Gidlewski, D.V.M., M.S., Kurt \\ VerCauteren, Ph.D., and Mo Salman, B.V.M.S., M.P.V.M., Ph.D., Dipl. A.C.V.P.M.
}

\begin{abstract}
An ungulate research facility in Fort Collins, Colorado, USA, experienced mortality in white-tailed deer (Odocoileus virginianus) because of epizootic hemorrhagic disease virus (EHDV) infection from 20 August 2007 through 26 September 2007. Epizootic hemorrhagic disease virus (EHDV) was detected by reverse transcriptase polymerase chain reaction and virus isolation from the spleen and lung tissues of two white-tailed deer. Virus neutralization tests were performed on pre- and postoutbreak sera from other species maintained in the same facility, including bison (Bison bison), elk (Cervus elaphus), domestic cattle (Bos taurus), and domestic goats (Capra hircus), as well as postoutbreak sera from the surviving white-tailed deer. Serum samples that represented all species in the facility neutralized EHDV-1 and EHDV-2 either before or after the outbreak. The animals that neutralized EHDV-1 did not neutralize EHDV-2. No clinical signs attributable to EHDV infection were noted in any of the species other than the deer during the outbreak. Although experimental EHDV infections have been reported in bison and elk, natural exposures have not been previously documented in these species in North America. The roles that elk, bison, cattle, and goats might play in the epidemiology of EHDV in a close-contact multispecies situation remain unknown.
\end{abstract}

Key words: Bison, Bison bison, cattle, Bos taurus, elk, Cervus elaphus, epizootic hemorrhagic disease, goat, Capra hircus, white-tailed deer, Odocoileus virginianus.

\section{INTRODUCTION}

Epizootic hemorrhagic disease virus (EHDV) (Orbivirus: Reoviridae) is an arbovirus transmitted by Culicoides spp. (Diptera: Ceratopogonidae). ${ }^{12}$ Epizootic hemorrhagic disease (EHD) is a World Organization for Animal Health (OIE)

From the U.S. Department of Agriculture (USDA)/ Animal and Plant Health Inspection Service (APHIS) Veterinary Services (Nol, Rhyan), USDA/APHIS Wildlife Services (Gidlewski, Vercauteren), National Wildlife Research Center, Fort Collins, Colorado 80521, USA; the Centers for Disease Control and Prevention, 1600 Clifton Road NE, MS G-13, Atlanta, Georgia 30333, USA (Kato); USDA/ARS Arthropod-Borne Animal Diseases Research Laboratory, Laramie, Wyoming 82072, USA (Reeves); the Department of Microbiology, Immunology and Pathology, College of Veterinary Medicine and Biomedical Sciences, Colorado State University, Fort Collins, Colorado 80523, USA (Spraker); the Department of Clinical Sciences, College of Veterinary Medicine and Biomedical Sciences, Colorado State University, Fort Collins, Colorado 80523, USA (Nol, Salman). Present address (Reeves): USAG-J, Unit 45013, Box 2582, Apo, AP 96338, USA. Correspondence should be directed to Dr. Nol (pauline.nol@aphis. usda.gov). reportable Multiple Species List disease. Infection by EHDV, of which there are three North American serotypes, EHDV-1, EHDV-2, and EHDV-6, can cause significant morbidity and mortality in free-ranging and captive white-tailed deer (Odocoileus virginianus). ${ }^{1,9,14}$ Clinical signs of EHD in white-tailed deer are highly variable. Initial signs can include depression, fever, respiratory distress, and, sometimes, rapid death..$^{7,9}$ Animals that do not die of acute disease can develop a chronic form of EHD typified by lameness and continued lethargy and inappetence as a result of hoof deformation and ulceration within the rumen and the gastrointestinal tract. ${ }^{7}$ EHD is clinically indistinguishable from disease caused by bluetongue virus (BTV) infection in cervids. ${ }^{11,20}$ Laboratory infections by EHDV have been reported in ungulates found in North America, such as American bison (Bison bison), and elk (Cervus elaphus subsp.), in addition to white-tailed deer. ${ }^{15,26}$ Natural infections occur in mule deer (Odocoileus hemionus subsp.), pronghorn antelope (Antilocapra americana), bighorn sheep (Ovis canadensis subsp.), cattle (Bos taurus), goats (Capra spp.), and sheep (Ovis aries). ${ }^{5,9,10,16,19,22,27}$ Similar to white-tailed deer, clini- 
cal signs of EHDV infection in these species vary greatly, depending on the species and individual host. Many exotic ungulates that have been introduced to North America are susceptible to EHDV, including Oryx spp., and various deer species. ${ }^{13,27}$ The aim of this article is to describe an outbreak of EHD and document exposure to EHDV in several species being held in a research facility at Colorado State University.

\section{Description of the facility}

The Colorado State University, Animal Population Health Institute/U.S. Department of Agriculture, Animal and Plant Health Inspection Service Wildlife Research Facility occupies approximately 2.6 ha and is located in Fort Collins, Colorado 80521, USA (Lat: $40^{\circ} 35^{\prime} 23^{\prime \prime} \mathrm{N}$; Long: $\left.-105^{\circ} 8^{\prime} 58^{\prime \prime} \mathrm{E}\right)$. Species held in this facility at the time of the 2007 outbreak included white-tailed deer, elk, bison, cattle, and goats.

\section{Initial outbreak and index cases}

On 20 August 2007, a 2-yr-old female whitetailed deer was found dead in its pen; there was no history of illness. The deer was part of a handraised captive herd of 12 animals that were obtained as fawns from a captive herd in Missouri, USA. At necropsy, lesions included severe edema of the lungs, with a prominent reticular pattern in all lobes. The chest cavity contained approximately $1 \mathrm{~L}$ of serosanguineous fluid. The serosal surface of the jejunum was multifocally and variably dark red, with moderate amounts of intraluminal dark red fluid. Tissues were submitted to Colorado State University for further diagnostics. Microscopic findings included pulmonary edema, with fibrinoid necrosis of the vessel walls; lymphoid depletion (primarily B cells) and congestion of the spleen; and endothelial swelling and edema of the small arterioles of the heart, as well as in the arcuate and interlobular arteries of the kidney. Other tissues examined included the cerebral retes, cerebrum, corpus striatum, pituitary gland, Gasserian ganglia, tongue, soft palate, tonsil, abomasum, duodenum, rumen, urinary bladder, and liver. The liver, tonsil, and soft palate exhibited congestion but no other lesions. There was no histologic evidence of mononuclear cell accumulation or other evidence of malignant catarrhal fever-causing herpes viruses in any of the tissues examined. No histologic evidence of bacterial pneumonia was detected. Because intestinal hemorrhage was suspected, tests were performed for Clostridium spp. and
Salmonella spp.; however, neither genus was isolated on fecal culture. There was mixed growth on aerobic fecal culture. The laboratory obtained a weak positive for Clostridium perfringens toxin. Reverse transcriptase polymerase chain reaction (RT-PCR) performed on spleen tissue was positive for EHDV and negative for BTV. Based on the PCR results and lesions that were highly suggestive of EHD, the diagnosis regarding the cause of mortality in this deer was EHDV infection. ${ }^{17,23}$ On 16 and 26 September 2007, two more white-tailed deer, respectively, were found dead, with similar pathologic findings. Beginning on 15 August 2007, a bull elk was observed to be lethargic for several days but appeared to recover. The elk was euthanized on 10 October 2007 because of traumatic injuries.

\section{Sample types and collection methods}

Before the outbreak, sera from the goats $(n=$ $19)$, elk $(n=13)$, cattle $(n=11)$, and bison $(n=7)$ were collected on 4 April 2007 (138 days before the outbreak) (goats), 6 July 2007 (45 days before the outbreak) (elk), and 11 July 2007 (40 days before the outbreak) (cattle and bison) for other reasons. The same animals and several additional elk were resampled after the outbreak, on 4 October 2007 ( 8 days after the outbreak) (goats and elk), and 5 October 2007 ( 9 days after the outbreak) (cattle and bison). Sera were collected from the remaining white-tailed deer $(n=9)$, on 15 November 2007 (50 days after the outbreak); however, no samples from the white-tailed deer were available from the preoutbreak period. In addition, spleen and lung tissue were collected from two white-tailed deer, not including the index case, that died on 16 and 26 September 2007, respectively, and from one elk that was euthanized on 10 October 2007 because of severe injuries.

\section{Testing procedures}

Both pre- and postoutbreak sera were tested in quadruplicate for antibodies against EHDV at the USDA/ARS Arthropod-Borne Animal Diseases Research Laboratory by virus neutralization by using the protocol described previously for EHDV-1 and EHDV-2. ${ }^{23,25}$ All sera were diluted 1:10 in minimal essential media. The animals were considered positive if their sera neutralized EHDV on all replicates. Virus isolates from the lung of an affected deer were neutralized by using the same protocol.

Total ribonucleic acid (RNA) was extracted from the spleen and lung tissue of three white- 
tailed deer and one elk by using an RNeasy Kit (QIAGEN, Valencia, California 91355, USA). The RNA was eluted in $30 \mu \mathrm{l}$ of nuclease free water by using the manufacturer's protocol. The extracts were then screened for RNA from EHDV by RT-PCR by using the reaction conditions described previously. ${ }^{3}$ Additional RT-PCR was conducted on the positive samples by using the same thermocycling conditions with primers EHDv63-F1 (5'-AACAGTTACTACGCAAAT CA-3') and EHDv245-R1 (5'-AGCCATTT CAGCCAATCT-3') to amplify a portion of the NS1 gene. A positive control that consisted of RNA extracts from cultured EHDV-1 and distilled water negative controls were used. The PCR products were separated by $3 \%$ agarose gel electrophoresis and visualized under ultraviolet light with GelStar (Cambrex BioScience Rockland, Inc., Rockland, Maine 04841, USA). The PCR products were purified with a QIAquick PCR Purification Kit (QIAGEN) and sequenced by using a BigDye Terminator v3.1 Cycle Sequencing Kit (Applied Biosystems, Foster City, California 94404 , USA) by using PCR primers. Sequences were determined by using an ABI 3700 capillary sequencer (Applied Biosystems), aligned and assembled with Chromas Lite 2.01 (Technelysium Pty. Ltd., Tewantin, Queensland, 4565, Australia) and ClustalW (Kyoto University Bioinformatics Center, Institute for Chemical Research, Kyoto University, Uji, Kyoto, 6110011, Japan), and were compared with sequences in GenBank by using the BLAST 2.0 program (National Center for Biological Information, Bethesda, Maryland 20814, USA).

The RNA extracts were screened for the presence of BTV by real time RT-PCR by using primers BTV-11F (5'-GTCGCTGCCATGCT ATCC-3') and BTV-246R (5'-CGTACGATGC GAATGCAG-3') and a probe BTV-p1 (5'-HEXGCTGATCCAAAGGTTCGA-BHQ1-3') (IDT Inc., Coralville, Iowa 52241, USA). These primers target the BTV NS3 protein (S10). Reactions were prepared by mixing $2.5 \mu \mathrm{l}$ of template RNA in a 96-well optical reaction plate (Applied Biosystems) with $0.5 \mu \mathrm{l}$ of both forward and reverse primers (100 $\mu \mathrm{mol}$ stock concentrations). The mixture was denatured at $95^{\circ} \mathrm{C}$ for $3 \mathrm{~min}$ and then chilled. A Taqman one-step RT-PCR Master Mix (Applied Biosystems) was used. The PCR master mix for each reaction was $12.5 \mu \mathrm{l}$ of $2 \times$ master mix, $0.625 \mu \mathrm{l}$ of $40 \times$ MultiScribe (Applied Biosystems), $8.6 \mu 1$ of RNase free water, and $0.1 \mu \mathrm{l}$ of BTV-p1 (stock concentration $100 \mu \mathrm{mol})$. Reaction conditions were $50^{\circ} \mathrm{C}$ for $30 \mathrm{~min}, 95^{\circ} \mathrm{C}$ for $10 \mathrm{~min}$, and 40 cycles of $95^{\circ} \mathrm{C}$ for $30 \mathrm{sec}, 52^{\circ} \mathrm{C}$ for $30 \mathrm{sec}, 72^{\circ} \mathrm{C}$ for $1 \mathrm{~min}$. The positive control consisted of double stranded RNA (dsRNA) from BTV-22 and distilled water as the negative control.

Virus isolation was attempted in triplicate from spleen and lung tissues positive for EHDV by RT-PCR. Approximately $500 \mathrm{mg}$ of tissue was homogenized by using the protocol described previously for Culicoides spp. ${ }^{18}$ One milliliter of tissue homogenate was then placed on $100 \mu \mathrm{l}$ of cattle pulmonary artery endothelial (CPAE) cells $\left(2.5 \times 10^{5}\right.$ cells $\left./ \mathrm{ml}\right)$. All the cells were incubated at $37^{\circ} \mathrm{C}$ with 5-6\% carbon dioxide for 7 days. The cells were checked for cytopathic effect after $48 \mathrm{hr}$ and 7 days. RNA was extracted from wells that showed cytopathic effect, and homogenate from these wells was passed to fresh CPAE and Vero cells. The RNA was tested for EHDV by RTPCR as described above. The PCR products were purified with a QIAquick PCR Purification Kit (QIAGEN). Duplicate sequencing reactions were performed with a BigDye Terminator v3.1 Cycle Sequencing Kit (Applied Biosystems) by using PCR primers, and excess dye was removed with a DyeEx 2.0 column (QIAGEN). Sequences were determined by using an ABI 3100 capillary sequencer (Applied Biosystems). Primer sequences were removed, and sequences were assembled with Seqmerge (Accelrys, San Diego, California). Assembled sequences were compared with those in GenBank by using the BLAST 2.0 program (National Center for Biological Information). The complementary DNA (cDNA) sequence from the NS3 gene of EHDV-2 was deposited in GenBank (EU595029).

\section{Serology results}

Preoutbreak sera from nine goats, four bison, and one cow neutralized EHDV-1 and preoutbreak sera from one cow and three elk neutralized EHDV-2. Postoutbreak sera from three goats, three elk, and one deer neutralized EHDV-1. Postoutbreak sera from seven goats, one deer, two elk, three bison, and two cattle neutralized EHDV-2 in all four virus neutralization replicates. None of the animals that neutralized EHDV-2 after the outbreak neutralized EHDV-1 after the outbreak. Two of the three elk that were seropositive for EHDV-2 before the outbreak lost neutralizing antibodies. None of the goats seropositive for EHDV-1 before the outbreak were positive for EHDV-1 after the outbreak. Data are summarized in Table 1. The euthanized elk with a history of clinical illness 
Table 1. Number of animals positive by serum neutralization for antibody against EHDV-1 and EHDV-2 over the number of animals tested for each species. ${ }^{a}$

\begin{tabular}{lccccc}
\hline & \multicolumn{3}{c}{ EHDV-1 } & & \multicolumn{2}{c}{ EHDV-2 } \\
\cline { 2 - 3 } \cline { 5 - 6 } & Preoutbreak & Postoutbreak & & Preoutbreak & Postoutbreak \\
\hline Cattle & $1 / 11$ & $0 / 11$ & & $1 / 11$ & $2 / 11^{\mathrm{b}}$ \\
Bison & $4 / 7$ & $0 / 7$ & & $0 / 7$ & $3 / 7$ \\
Goats & $9 / 19$ & $3 / 19^{\mathrm{c}}$ & & $0 / 19$ & $7 / 19$ \\
Elk & $0 / 13$ & $3 / 19$ & $3 / 13$ & $2 / 19^{\mathrm{b}, \mathrm{d}}$ \\
White-tailed deer & N/A & $1 / 9$ & N/A & $1 / 9$ \\
\hline
\end{tabular}

${ }^{a}$ EHDV, epizootic hemorrhagic disease virus; N/A, not applicable.

${ }^{\mathrm{b}}$ One animal in the group was seropositive at both sample events.

${ }^{\mathrm{C}}$ Goats seropositive for EHDV-1 in the postoutbreak period were not the same as those seropositive in the preoutbreak period.

${ }^{\mathrm{d}}$ One seropositive animal in the group was not sampled in the preoutbreak period.

was among those positive for neutralizing antibodies for EHDV-2 in preoutbreak serum but not in postoutbreak serum.

\section{Molecular analysis and virus isolation results}

By using RT-PCR, cDNA was amplified from EHDV from spleen and lung tissue of the two white-tailed deer that died on the 16 and 26 September 2007, respectively. Epizootic hemorrhagic disease virus (EHDV) was isolated on CPAE cells from the spleen of the animal that died on 16 September 2007 and from both lung and spleen from the animal that died on 26 September 2007. No other viruses were isolated. Virus isolated from the lung tissue was neutralized by antisera against EHDV-2 but not EHDV1. The viruses isolated from the spleens could not be maintained in cell culture long enough to perform neutralization testing. The NS3 and NS1 gene sequences were identical between the spleen and lung tissues of the animals and $>99 \%$ similar to previously sequenced isolates of EHDV-2 (AY714647, X59000) in GenBank. The 2 base pair differences in the NS3 sequence were silent mutations and did not change the predicted amino acids sequence, which was identical to that of EHDV-2. No cDNA from EHDV could be amplified in the spleen from the euthanized elk bull nor was virus isolated from this tissue.

\section{DISCUSSION}

To the authors' knowledge, this is the first report of serologic evidence of natural exposure to EHDV in elk and bison. Although antibody production against EHDV has been reported in both species after experimental infection, serologic and viral evidence of natural infection of EHDV in these two species in North America have not been previously documented in the published literature. Unpublished cases of EHDV in elk have been reported by cervid farmers (Reeves, pers. comm.). ${ }^{15,26}$ Numerous outbreaks of EHDV-2 occurred during 2007 throughout North America. Some affected regions were areas where the disease had previously never been reported (D. E. Stallknecht, 2008, unpubl. data). Serologic surveys for EHD have been performed in wild populations of North American elk; however, to date, the presence of antibodies to EHDV has not been detected. ${ }^{4,15,16}$ Similar to elk, evidence of exposure to EHDV in wild bison herds has been investigated but not confirmed, although antibodies to BTV have been documented in free-ranging bison. ${ }^{28,29}$

It is possible that, in a captive setting with multiple species, such as that at the Wildlife Research Facility, bison and elk, in addition to cattle, may have served as asymptomatic sources of the virus to more susceptible species, such as white-tailed deer. There is experimental evidence that infection and viremia can occur in both bison and elk. In a previous study in which elk were experimentally inoculated with EHDV, the investigators found red blood cell-associated virus up to 30 days after infection. ${ }^{15}$ Aside from mild fever in one elk, they found no other clinical signs associated with this experimental infection. In an unrelated study, the investigators describe inadvertently infecting bison with EHDV during an experimental BTV infection trial, wherein one of the six bison in the experimental trial became viremic with EHDV. The inocula had been provided by the Arthropod-Borne Animal Diseases Research Laboratory, which later verified contamination of its laboratory stocks with EHDV-2. ${ }^{26}$ As with elk, no clinical signs were noted from either BTV or EHDV infection in bison, although the potential effects of coinfection on this outcome remain unclear. Cattle are 
susceptible to EHDV infection and, in rare cases, suffer severe disease. ${ }^{22}$ Cattle are frequently used as sentinels for EHDV, BTV, and other orbiviruses because they can sustain subclinical infections and seroconvert, and are capable of amplifying virus. ${ }^{2}$ It is possible that cattle serve as a source or reservoir of virus during outbreaks of disease in deer or other susceptible species. As expected, cattle housed at the Wildlife Research Facility did not exhibit any clinical signs of EHD, although they potentially contributed to the epidemiology of the outbreak.

The reason for loss of neutralizing antibodies in the cattle, elk, bison, and especially in the goats, is currently unknown. The lack of evidence of coinfection with EHDV-1 and EHDV-2 is also interesting, because the neutralization data indicate some activity of both viruses, although EHDV-1 could not be isolated from any of the affected animals. The animals seropositive for EHDV-1 before the 2007 EHDV outbreak were likely exposed to EHDV-1 in the previous year(s) and could have experienced a waning of antibody to below the assay detection level by the postoutbreak period and then may have avoided any further exposure. Those animals that apparently developed neutralizing antibodies to serotype 1 may have been experiencing new infections, or there is a possibility that the assay was detecting cross-reactive antibodies, particularly at the 1:10 dilution level., ${ }^{9,24}$ Recent evidence of novel Orbivirus infections in European goats could make serology in this species difficult to interpret without obtaining virus isolations, ${ }^{6}$ which were not done in this study. Viremia in goats has yet to be documented, even in an experimental setting, although antibodies to EHDV have been detected. Some goats are considered refractory to EHDV infection but that is not considered true for all goat breeds. ${ }^{27} \mathrm{In}$ a study conducted in goats in Georgia (USA), a low seroprevalence of EHDV was reported; however, these animals were tested with an assay that is known to cross-react with antibodies to other orbiviruses, e.g., BTV. ${ }^{8,21}$

The 2007 outbreak of hemorrhagic disease caused by EHDV-2 in white-tailed deer in a captive research facility created a unique opportunity to explore serologic data from multiple species in close proximity to the affected deer. The results indicated that natural exposures to EHD viruses occurred in goats, elk, bison, and cattle, likely in years previous to the outbreak as well as during the outbreak. The roles these seroconverting species might have played in the transmission of the viruses are unknown. Controlled investigations that involve experimental EHDV infection and transmission would allow researchers to examine more closely the potential of these species to participate in the epidemiology of this disease.

Acknowledgments: The authors thank A. Fabian, L. McHolland, W. Wilson, and W. Yarnell for their valuable assistance with field and laboratory research. Additional appreciation goes out to T. Fry, K. Held, T. Martin, M. McCollum, and R. Thompson for their help in animal handling and sample collections. The use of trade names does not constitute an official endorsement or approval of the use of any such products, commercial hardware or software by the U.S. Department of Agriculture. The authors request that this article not be cited for advertisement purposes.

\section{LITERATURE CITED}

1. Allison, A. B., G. H. Goekjian, C. Potgieter, W. Wilson, D. Johnson, P. P. C. Mertens, and D. Stallknecht. 2009. Detection of a novel reassortant epizootic hemorrhagic disease virus in the United States containing RNA segments derived from both exotic and endemic serotypes. J. Gen. Virol. 91: 430-439.

2. Aradaib, I. E., M. M. Sawyer, and B. I. Osburn. 1994. Experimental epizootic hemorrhagic disease virus infection in calves: virological and serological studies. J. Vet. Diagn. Invest. 6: 489-492.

3. Aradaib, I. E., W. C. Wilson, C. E. Schore, M. E. H. Mohammed, T. D. Yilma, J. S. Cullor, and B. I. Osburn. 1998. PCR detection of North American and central African isolates of epizootic hemorrhagic disease virus (EHDV) based on genome segment 10 of EHDV serotype 1. J. Clin. Microbiol. 36: 2604-2608.

4. Barber-Meyer, S. M., P. J. White, and L. D. Mech. 2007. Survey of selected pathogens and blood parameters of northern Yellowstone elk: wolf sanitation effect implications. Am. Midl. Nat. 158: 369-381.

5. Brodie, S. J., K. D. Bardsley, K. Diem, J. O. Mecham, S. E. Norelius, and W. C. Wilson. 1998. Epizootic hemorrhagic disease: analysis of tissues by amplification and in situ hybridization reveals widespread orbivirus infection at low copy numbers. J. Virol. 72: 3863-3871.

6. Chaignat, V., G. Worwa, N. Scherrer, M. Hilbe, F. Ehrensperger, C. Batten, M. Cortyen, M. Hofmann, and B. Thuer. 2009. Toggenburg Orbivirus, a new bluetongue virus: initial detection, first observations in field and experimental infection of goats and sheep. Vet. Microbiol. 138: 11-19.

7. Davidson, W. R., and V. F. Nettles (eds.). 1997. White-tailed Deer: Hemorrhagic Disease, 2nd ed. Southeastern Cooperative Wildlife Disease Study, Athens, Georgia. 
8. Della-Porta, A. J. 1985. Problems in the interpretation of diagnostic tests due to cross-reactions between orbiviruses and broad serological responses in animals. In: Barber, T. L., and M. M. Jochim (eds.). Bluetongue and Related Orbiviruses. Alan R. Liss, Inc, New York, New York. Pp. 445-453.

9. Dubay, S. A., J. C. deVos, T. H. Noon, and S. Boe. 2004. Epizootiology of hemorrhagic disease in mule deer in central Arizona. J. Wildl. Dis. 40: 119-124.

10. Dubay, S. A., S. S. Rosenstock, D. E. Stallknecht, and J. C. deVos. 2006. Determining prevalence of bluetongue and epizootic hemorrhagic disease viruses in mule deer in Arizona (USA) using whole blood dried on paper strips compared to serum analyses. J. Wildl. Dis. 42: 159-163.

11. Flacke, G. L., M. J. Yabsley, B. A. Hanson, and D. E. Stallknecht. 2004. Hemorrhagic disease in Kansas: enzootic stability meets epizootic disease. J. Wildl. Dis. 40: 288-293.

12. Foster, N. M., R. D. Breckon, A. J. Luedke, R. H. Jones, and H. E. Metcalf. 1977. Transmission of two strains of epizootic hemorrhagic disease virus in deer by Culicoides variipennis. J. Wildl. Dis. 13: 9-16.

13. Frolich, K., C. Hamblin, S. Jung, S. Ostrowski, J. Mwanzia, W. J. Streich, J. Anderson, R. M. Armstrong, and S. Anajariyah. 2005. Serologic surveillance for selected viral agents in captive and freeranging populations of Arabian oryx (Oryx leucoryx) from Saudi Arabia and the United Arab Emirates. J. Wildl. Dis. 41: 67-79.

14. Gaydos, J. K., J. M. Crum, W. R. Davidson, S. S. Cross, S. F. Owen, and D. E. Stallknecht. 2004. Epizootiology of an epizootic hemorrhagic disease outbreak in West Virginia. J. Wildl. Dis. 40: 383-393.

15. Hoff, G. L., and D. O. Trainer. 1973. Experimental infection in North American elk with epizootic hemorrhagic disease virus. J. Wildl. Dis. 9: 129-132.

16. Jessup, D. A. 1985. Epidemiology of two orbiviruses in California's native wild ruminants: preliminary report. In: Barber, T. L., and M. M. Jochim (eds.). Bluetongue and Related Orbiviruses. Alan R. Liss, New York, New York. Pp. 53-65.

17. Karstad, L., A. Winter, and D. O. Trainer. 1961. Pathology of epizootic hemorrhagic disease in deer. Am. J. Vet. Res. 22: 227-235.

18. Kato, C. Y., and R. T. Mayer. 2007. An improved, high-throughput method for detection of bluetongue virus RNA in Culicoides midges utilizing infrared-dye-labeled primers for reverse transcriptase PCR. J. Virol. Methods 140: 140-147.
19. Lundervold, M., E. Milner-Gulland, C. O'Callaghan, C. Hamblin, A. Corteyn, and A. Macmillan. 2004. A serological survey of ruminant livestock in Kazakhstan during post-Soviet transitions in farming and disease control. Acta Vet. Scand. 45: 211-224.

20. Murphy, M. D., E. W. Howerth, N. J. MacLachlan, and D. E. Stallknecht. 2005. Genetic variation among epizootic hemorrhagic disease viruses in the southeastern United States: 1978-2001. Infect. Genet. Evol. 5: 157-165.

21. Odiawa, G., J. L. Blue, D. E. Tyler, and E. B. Shotts. 1985. Bluetongue and epizootic hemorrhagic disease in ruminants in Georgia: survey by serotest and virologic isolation. Am. J. Vet. Res. 46: 2193-2196.

22. Ohashi, S., K. Yoshida, Y. Watanabe, and T. Tsuda. 1999. Identification and PCR-restriction fragment length polymorphism analysis of a variant of the Ibaraki virus from naturally infected cattle and aborted fetuses in Japan. J. Clin. Microbiol. 37: 3800-3803.

23. Quist, C. F., E. W. Howerth, D. E. Stallknecht, J. Brown, T. Pisell, and V. F. Nettles. 1997. Host defense responses associated with experimental hemorrhagic disease in white-tailed deer. J. Wildl. Dis. 33: $584-599$

24. Stallknecht, D. E., M. P. Luttrell, K. E. Smith, and V. F. Nettles. 1996. Hemorrhagic disease in whitetailed deer in Texas: a case for enzootic stability. J. Wildl. Dis. 32: 695-700.

25. Stallknecht, D. E., V. F. Nettles, E. A. Rollor, and E. W. Howerth. 1995. Epizootic hemorrhagic disease virus and bluetongue virus serotype distribution in white-tailed deer in Georgia. J. Wildl. Dis. 31: 331338

26. Tessaro, S. V., and A. Clavijo. 2001. Duration of bluetongue viremia in experimentally infected American bison. J. Wildl. Dis. 37: 722-729.

27. Thevasagayam, J. A. 1998. The Epizootic Haemorrhagic Disease Virus Serogroup. Ph.D. Dissertation, Univ. Hertfordshire, Hertfordshire, United Kingdom

28. Vestweber, J., G. Merrill, J. Staats, and J. Veatch. 1991. Serologic survey for selected microbial pathogens in bison from Kansas. J. Wildl. Dis. 27: 473476.

29. Zarnke, R. 1983. Serologic survey for selected microbial pathogens in Alaskan wildlife. J. Wildl. Dis. 19: 324-329.

Received for publication 28 October 2009 